\title{
Coulometric Microdetermination of Surface Water on Various Metals and Glasses and of Hydrogen in Beryllium Metal*
}

\author{
By Takayoshi Yoshimori**, Shuiti Ishiwari***, Yoshio Watanabe**, \\ Takashi Harada** and Shoji Yamada**
}

\begin{abstract}
Water adsorbed on the surface of a sample was extracted into the carrier gas and then determined by the coulometric titration method. The water was extracted from a heated sample into argon and then converted into $\mathrm{NH}_{3}$ by means of $\mathrm{NaNH}_{2}$ at $80^{\circ} \mathrm{C}$. The $\mathrm{NH}_{3}$ was titrated with electrolytically generated $\mathrm{BrO}^{-}$ion.

The quantity of water adsorbed on the surfaces of steels varried depending on the roughness of the surfaces; $0.5 \sim$ $0.7 \mu \mathrm{g} / \mathrm{cm}^{2}$ on the filed surfaces and $0.2 \sim 0.3 \mu \mathrm{g} / \mathrm{cm}^{2}$ on the electropolished samples.

The results show that the adsorbed water should cause no measurable error in the determination of hydrogen in steel. The fractional determination of the surface water and hydrogen in a stainless steel was also possible. The water was first determined by heating the sample at $100 \sim 120^{\circ} \mathrm{C}$. Hydrogen in the sample was extracted at $1100^{\circ} \mathrm{C}$ and then determined after its oxidation to water.

The adsorbed and combined water on the surface of aluminum was also determined by this method. The amount of the water varied considerably by the storage condition of the sample.

Hydrogen in beryllium was extracted into argon by heating the sample at $1100^{\circ} \mathrm{C}$ and determined in a similar way. A sample contained $4.8 \mathrm{ppm}$ of hydrogen. The water evolved from the same metal was also determined, and considerable amounts of water $(21 \sim 23 \mathrm{ppm})$ were measured when heated the sample at 400 or $800^{\circ} \mathrm{C}$.

The water evolved from glasses by heating the sample at $300^{\circ} \mathrm{C}$ was determined similarly. A soft glass evolved $4 \sim 7 \mu \mathrm{g} / \mathrm{cm}^{2}$ water, and many hard glasses (Pyrex or others) $0.2 \sim 0.7 \mu \mathrm{g} / \mathrm{cm}^{2}$ water. The water adsorbed on the quartz surface was only $0.05 \sim 0.07 \mu \mathrm{g} / \mathrm{cm}^{2}$.
\end{abstract}

(Received December 29, 1972)

\section{Introduction}

The water adsorbed on the surface or combined with the oxide film of metals influences the results of analyses of gases in metals. The effect of the surface treatment of steel samples on the results of oxygen determinations was investigated by Kammori et al. ${ }^{(1)}$ The same effect on the determination of hydrogen in aluminium was also reported by Goto et al ${ }^{(2)}$ In these investigations, however, the water adsorbed on the surface of steels was estimated from the fluctuation in the analytical values of total oxygen in the samples whose surfaces were treated by various methods ${ }^{(1)}$, and the water on aluminum was analyzed by the hydrogen determination of the sample in which hydrogen had been previously extracted. The water itself evolved from the original sample has not been determined directly because of the extremely small amount of water beyond the sensibility of the analysis.

In the preceding papers, however, the present authors proposed a method for the microdetermina-

* Determination of water on aluminum is added to the paper presented in J. Japan Inst. Metals, 35 (1971), 808.

** Faculty of Engineering, Science University of Tokyo, Shinjuku-ku, Tokyo, Japan.

*** Graduate School, Science University of Tokyo, Tokyo. Present address: Musashi Works of Hitachi, Ltd., Kodaira, Tokyo, Japan.

(1) O. Kammori, N. Yamaguchi and R. Suzuki: J. Japan Inst. Metals, 32 (1968), 1190.

(2) H. Goto, M. Hosoya and Y. Otaka: ibid., 29 (1965), 876.

Trans. JM tion of water on the surfaces of weights ${ }^{(3)}$ and of hydrogen in metals ${ }^{(4)}$. The microamount of water extracted from a sample into argon carrier was converted to ammonia with sodium amide. The ammonia thus produced was determined with the coulometrically generated hypobromite ion. After its oxidation with copper (II) oxide, hydrogen was determined.

Since hydrogen does not react with sodium amide, a selective determination of water in hydrogen is possible by this method when a mixture of water and hydrogen is extracted from the sample into argon by heating at high temperature.

The amounts of surface water for steels and aluminum metals are determined directly by the proposed method after the treatment of the sample surfaces by various methods. Hydrogen and water in beryllium metal and the amounts of water evolved by heating various glasses are also determined by the same method.

\section{Experimentals}

\section{Apparatus and reagents}

The apparatus used for the determination of the surface water is shown in Fig. 1. Hydrogen and organic matters in argon was oxidized with copper (II) oxide $\left(600^{\circ} \mathrm{C}\right)$, and the gas was then purified with sodium

(3) T. Yoshimori and S. Ishiwari: Bull. Chem. Soc. Japan, 42 (1969), 1282.

(4) T. Yoshimori and S. Ishiwari: Talanta, 17 (1970), 349. 


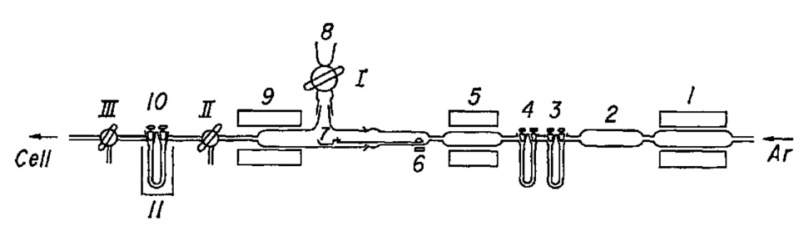

Fig. 1 Apparatus for extraction of water and conversion to ammonia.

1:CuO furnace 2: $\mathrm{NaOH} \quad 3: \mathrm{Mg}\left(\mathrm{ClO}_{4}\right)_{2} \quad 4: \mathrm{P}_{2} \mathrm{O}_{5}$ 5:Ti sponge 6: Magnet 7:Quartz boat 8:Sample inlet 9:Sample heater 10: $\mathrm{NaNH}_{2}$ 11:Oil bath I-III Cock

hydroxide, magnesium perchlorate, phosphorous pentoxide and heated titanium sponge $\left(700^{\circ} \mathrm{C}\right)$. A sample was dropped on a quartz boat $(10 \mathrm{~mm}$ in width, $50 \mathrm{~mm}$ in length) through the cock I (inner diameter $10 \mathrm{~mm}$ ) with the aid of a funnel. After the determination, ferromagnetic samples were taken out through the cock with a magnet, and non-magnetic samples were put out of the boat by releasing the ground glass joint under the cock. In many cases, however, it was possible to carry out a series of determinations continuously without taking off the metallic sample. Although the heating devices presented by Goto et al. ${ }^{(2)}$ and Oda et al. ${ }^{(5)}$ may also be of use, the present apparatus was more practical to experiment the samples of low melting point.

Sodium amide and quartz wool were packed alternatively in a U-tube ( $5 \mathrm{~mm}$ in diameter, about $100 \mathrm{~mm}$ in length of pass). The tube was heated at $80 \pm 0.1^{\circ} \mathrm{C}$ in a oil thermostat. Packings of amide, phosphorous pentoxide and magnesium perchlorate into the Utubes should be carried out in a glove box filled with dried nitrogen.

The cell for the coulometric titration of ammonia is shown in Fig. 2. The indicator electrodes were made of platinum wires $(0.5 \times 5 \mathrm{~mm})$. The generator electrode was a platinum foil $(1 \times 1 \mathrm{~cm})$, and an auxiliary elec-

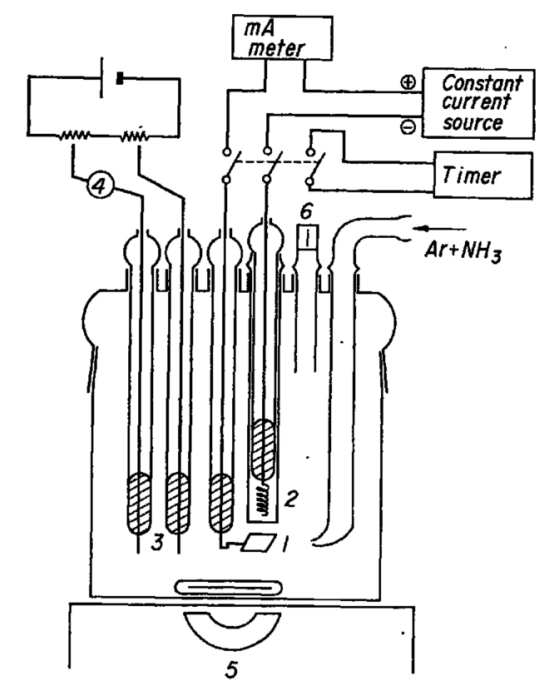

Fig. 2 Cell for coulometric titration.

1:Generating eleetrode 2:Auxiliary electrode 3:Indicator electrode pair 4: $\mu \mathrm{A}$ meter 5: Magnetic stirrer $6:$ Bunsen valve

(5) N. Oda, G. Tsuchihashi and S. Ono: Japan Analyst, 10 (1961), 251. trode was a coil of the same metal wire $(0.5 \times 50 \mathrm{~mm})$. The constant current source for the generation of the titrant was the vacuum tube device shown previously $^{(6)}$, and the time for the electrolysis was measured by a stopclock with a synchronous motor. The Apieson L greeze was best suited as the lubricant and the quartz tubes were used for the heating of titanium sponge, copper (II) oxide and a sample. All the glassware were made of Pyrex glass, and the use of rubber tubing had to be avoided. These precautions were very important to minimize the blank value.

The analytical grade reagents were used without purification. A buffer solution was prepared by dissolving $38.1 \mathrm{~g}$ of borax in $1 \mathrm{~L}$ of water, the $\mathrm{pH}$ of which was adjusted to 8.6 with perchloric acid. To fifty $\mathrm{mL}$ of the buffer, $25 \mathrm{~mL}$ of the $5 \mathrm{M}$ sodium bromide solution was added. The mixture was diluted with water to a volume $125 \mathrm{~mL}$ prior to its use as the electrolyte.

\section{Procedures}

\section{(1) Sample treatment}

Surfaces of the metallic samples were filed unless otherwise stated. Some samples were burnished with emery paper and then polished with chromium (III) oxide or with an electrolytic method ${ }^{(1)}$. After polishing, the samples were washed with acetone, then washed with ethyl ether by using a Soxlet apparatus. All the samples thus prepared were stored in a desiccator and used within the same day.

\section{(2) Preparation of the apparatus}

During the elevation of the temperature of the furnaces, all tubings and ground glass joints (without the tubes containing the reagents) were heated with flexible heaters to about $110^{\circ} \mathrm{C}$. In this period, argon was allowed to flow through the train at a rate of about $200 \mathrm{~mL} / \mathrm{min}$ and then evacuated through the cock II in Fig. 1. When the temperature of the furnaces was raised to the degree near the working state, the oil bath including U-tube of sodium amide was heated to $110^{\circ} \mathrm{C}$, and argon was allowed to flow through the tube and evacuated through the cock III. After 30 min, the temperature of the oil bath was lowered to $80 \pm 0.1{ }^{\circ} \mathrm{C}$, and argon was introduced into the titration cell. The flow rate of argon was decreased to $100 \mathrm{~mL} / \mathrm{min}$, and the flexible heaters were removed from the tubings. The potential difference between the indicator electrodes was adjusted to $0.2 \mathrm{~V}$.

\section{(3) Blank experiment}

The solution in the titration cell was electrolyzed with constant current (about $3 \mathrm{~mA}$ ) until the current of the indicator circuit rose to $0.4 \mu \mathrm{A}$. The solution was again electrolyzed for $5 \mathrm{~min}$ by the same method until the indicator current rose to $0.4 \mu \mathrm{A}$, and the time of the electrolysis and the current were recorded. This electrolysis was repeated at intervals of $5 \mathrm{~min}$ until the 
amount of the electricity decreased and became constant. This amount was to be the blank value for the period of $5 \mathrm{~min}$. If the amount of electricity does not become constant even after about 60 min of the blank experiment, or if it becomes much larger or extremely small, the phenomena indicate the deterioration of sodium amide and, therefore, the reagent should be replaced by the new one.

\section{(4) Determination of surface water}

The sample was put on the quartz boat in the heating tube through the cock I in Fig. 1 by using the funnel, and introduced into the furnace with the aid of a magnet. The cock I should not be opened over $30 \mathrm{sec}$, otherwise a measurable atmospheric moisture would enter the tube. After $5 \mathrm{~min}$, the ammonia absorbed with the solution in the cell was determined by the same method as in the blank experiment. The electrolysis was repeated at intervals of $5 \mathrm{~min}$ until the amount of electricity became the same value as that in the blank experiment.

\section{(5) Determination of hydrogen in metals}

For the determination of hydrogen in metals, the furnace containing the copper (II) oxide tube was placed between the furnace 9 and the cock II in Fig. 1. The other devices and the procedure were the same as those for the water determination.

\section{Results and Discussions}

\section{Determinations of water and hydrogen in stain- less steel}

\section{(1) Surface water on stainless steel}

Water on the surface of the filed or electrolytically polished stainless steel was determined, and the results obtained are shown in Table 1 . The amounts of surface water somewhat decreased for the electropolished sample, and increased slightly sample was heated at $800^{\circ} \mathrm{C}$. The difference between these results, however, was not so great as to affect the hydrogen determination. This conclusion is the same as that obtained by Kammori et al. ${ }^{(1)}$

(2) Fractional determination of surface water and hydrogen in the stainless steel

The surface water on the sample was first determined
Table 1 Determination of the water on the surfaces of the stainless steel.

\begin{tabular}{l|c|c|c|c}
\hline $\begin{array}{l}\text { Surface } \\
\text { treatment }\end{array}$ & $\begin{array}{c}\text { Heating } \\
\text { temperature } \\
\left({ }^{\circ} \mathrm{C}\right)\end{array}$ & $\begin{array}{c}\text { No. of } \\
\text { determi- } \\
\text { nations }\end{array}$ & $\begin{array}{c}\text { Water } \\
\text { on the } \\
\text { surface } \\
\left(\mu \mathrm{g} / \mathrm{cm}^{2}\right)\end{array}$ & $\hat{\sigma}^{(\mathbf{b})}$ \\
\hline Filing \{ & 800 & 5 & $\begin{array}{l}0.80 \\
0.57\end{array}$ & $\begin{array}{l}0.09 \\
0.21 \\
\text { Electropolishing }\end{array}$ \\
\hline \hline
\end{tabular}

(a) Calculated from the apparent surface area

(b) Calculated by $\hat{\sigma}=R / d_{2}$

by heating the sample at the position of the entrance of the heating furnace (No. 9 in Fig. 1) at which the temperature was about $100^{\circ} \mathrm{C}$. Hydrogen in the sample was then determined by heating at about $1100^{\circ} \mathrm{C}$ in the furnace. In this case, the furnace of copper (II) oxide was placed between the furnace 9 and the cock II in the figure. The results are summarized in Table 2.

The results in this table indicate that the fractional determination is possible by this method and that the surface water is released from the sample at about $100^{\circ} \mathrm{C}$. The difference in the amounts of water by changing the treatment of the surface was the same as that in Table 1. Thus filing of the surface should be enough for the treatment of the sample in the ordinary hydrogen analysis:

\section{Determination of surface water on a plain carbon steel}

Water on the surface of the carbon steel was determined by the present method, and the results are shown in Table 3.

Nearly the same amount of water as presented in Table 1 was determined for the filed sample. When polished electrolytically, the sample was apt to rust and to give an extraordinarily high value. Therefore, the wet process was not recommendable for the surface treatment of this material.

\section{Determination of surface water on aluminum}

The surface water on aluminum metal was determined by heating the sample at various temperatures. All the samples were treated by filing and then stored in various conditions. No other polishing methods of the sample surface were not considered here for the following two reasons; first the filing method is the

Table 2 Fractional determination of the hydrogen in a stainless steel and the water on its surface. (Sample: $10.5 \% \mathrm{Ni}$, $20.0 \% \mathrm{Cr}$ )

\begin{tabular}{|c|c|c|c|c|c|}
\hline \multirow{2}{*}{ Surface treatment } & \multirow{2}{*}{$\begin{array}{l}\text { No. of } \\
\text { determinations }\end{array}$} & \multirow{2}{*}{$\begin{array}{l}\text { Water on the } \\
\text { surface } \\
\left(\mu \mathrm{g} / \mathrm{cm}^{2}\right)\end{array}$} & \multirow{2}{*}{$\begin{array}{l}\text { Hydrogen in } \\
\text { the sample } \\
\text { (ppm) }\end{array}$} & \multicolumn{2}{|c|}{ Total hydrogen } \\
\hline & & & & (ppm) & $\hat{\sigma}$ \\
\hline $\begin{array}{l}\text { Filing }\{ \\
\text { Emery paper }\left\{\begin{array}{l}\text { No. } 320 \\
\text { No. } 1000\end{array}\right. \\
\text { Buff with } \mathrm{Cr}_{2} \mathrm{O}_{3}\end{array}$ & $\begin{array}{l}4^{(c)} \\
5^{(c)} \\
2 \\
2 \\
3 \\
5\end{array}$ & $\begin{array}{l}0.55 \\
0.71 \\
0.52 \\
0.47 \\
0.40 \\
0.30\end{array}$ & $\begin{array}{l}3.86 \\
3.81 \\
3.84 \\
3.66 \\
3.62 \\
3.84\end{array}$ & $\begin{array}{l}3.94 \\
3.93 \\
3.92 \\
3.73 \\
3.68 \\
3.89\end{array}$ & $\begin{array}{l}0.15 \\
0.09 \\
0.06 \\
0.09 \\
0.13 \\
0.11\end{array}$ \\
\hline
\end{tabular}

(a) The water was extracted by heating the sample at $100 \sim 120^{\circ} \mathrm{C}$.

(b) The sample was heated at $1100^{\circ} \mathrm{C}$ after the determination of the water.

(c) Analyzed by different analysis. 
Table 3 Determination of the water on the filed surface of a carbon steel. (Sample; C: $0.07 \%$, Si: $0.01 \%, \mathrm{Mn}: 0.52 \%$ )

\begin{tabular}{c|c|c}
\hline \multirow{2}{*}{ Heating temperature } & \multicolumn{2}{|c}{ Water found $\left(\mu \mathrm{g} / \mathrm{cm}^{2}\right)$} \\
\cline { 2 - 3 }$\left({ }^{\circ} \mathrm{C}\right)$ & Mean $^{(\mathrm{a})}$ & $\hat{\sigma}$ \\
\hline 800 & 0.53 & 0.16 \\
400 & 0.41 & 0.03 \\
\hline
\end{tabular}

(a) Mean value of 4 determinations

simplest, and secondly the effect of the surface treatments has already been investigated comprehensively by Goto et al. ${ }^{(2)}$

The amounts of water evolved from the filed samples at various temperature are shown in Fig. 3. The released amount of water at $600^{\circ} \mathrm{C}$ was about one half of the value in the previous report ${ }^{(2)}$. This difference is likely to be due to both the atmospheric condition in which the sample was filed and the condition of the sample storage. In present case the sample was filed in the atmosphere of $50 \sim 60 \%$ humidity (about $20^{\circ} \mathrm{C}$ ) and then stored in a desiccator.

The effect of the storage of the sample was then investigated, and the results are shown in Table 4. In order to avoid any reaction between the silica boat and alumina on the surface of sample, all the samples were heated at $400^{\circ} \mathrm{C}$. It may be concluded from these results that the samples adsorbs a greater amount of

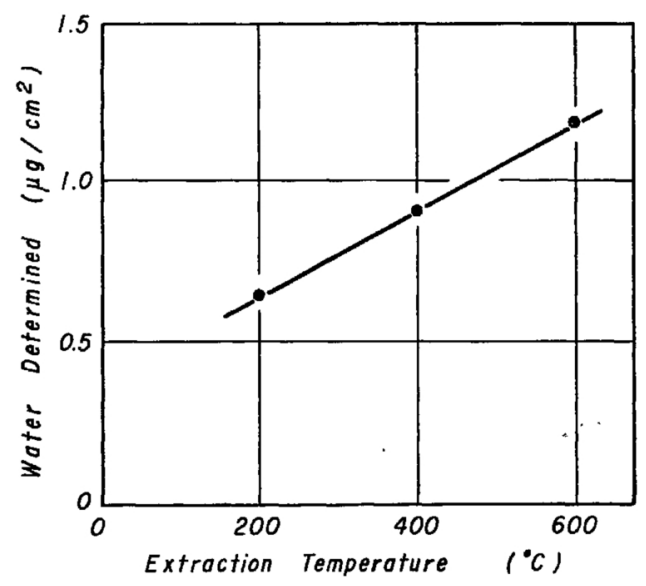

Fig. 3 Determination of the water on the filed surfaces of aluminum by heating at various temperatures.

Sample: Filed in atmosphere (about $22^{\circ} \mathrm{C}, 65 \%$ humidity) and stored in a desiccator for less than $1.5 \mathrm{hr}$.

Table 4 Determination of the amounts of water adsorbed on the filed surfaces of the aluminum samples stored in various conditions. Heating temperature for extraction: $400^{\circ} \mathrm{C}$.

\begin{tabular}{c|c|c|c|c}
\hline $\begin{array}{c}\text { Relative } \\
\text { humidity } \\
(\%)^{*}\end{array}$ & $\begin{array}{c}\text { Time of } \\
\text { storage } \\
(\mathrm{hr})\end{array}$ & $\begin{array}{c}\text { No. of } \\
\text { detns. }\end{array}$ & \multicolumn{2}{|c}{$\mathrm{H}_{2} \mathrm{O}$ found $\left(\mu \mathrm{g} / \mathrm{cm}^{2}\right)$} \\
\cline { 4 - 5 } & 23 & 5 & 1.23 & 0.39 \\
52 & 72 & 5 & 1.54 & 0.32 \\
52 & 23 & 5 & 2.24 & 0.08 \\
78 & 74 & 3 & 2.22 & 0.22 \\
78 & &
\end{tabular}

*Approximate value at $20 \sim 25^{\circ} \mathrm{C}$ water on their surface when stored in a condition of higher humidity, but the amount of the water does not increase appreciably by the prolonged storage. These conclusions are nearly the same as those reported previously ${ }^{(2)}$.

\section{Determination of hydrogen and water in beryllium}

The result of hydrogen determination in beryllium has not been found in the literature. Therefore, both total hydrogen and water evolved by heating the metal were determined by the proposed method, and the results are shown in Table 5. The sample used here was obtained by cutting a bar of the metal, and its surface was washed with acetone.

The data in the table indicate that the amounts of the water in the metal (or on its surface) were unusually large and almost all of it could be evolved by heating the sample at a temperature higher than $400^{\circ} \mathrm{C}$. Since about one half of the total hydrogen in the sample is contained as water, it can be anticipated that the other methods now available for hydrogen determination (vacuum fusion technique, carrier gas extraction followed by the separation with palladium diaphragm process, etc.) should involve a complicated procedure for the analysis of this sort of metal. However, because of the difficulties for the handling of the sample, no further study on the state of water in the sample was made here.

Table 5 Determination of amounts of hydrogen and water in a beryllium metal.

\begin{tabular}{c|c|c|c}
\hline $\begin{array}{c}\text { Heating } \\
\text { temp. } \\
\left({ }^{\circ} \mathrm{C}\right)\end{array}$ & $\begin{array}{c}\text { No. of } \\
\text { determi- } \\
\text { nations }\end{array}$ & $\begin{array}{c}\text { Water found } \\
(\mathrm{ppm})\end{array}$ & $\begin{array}{c}\text { Total } \\
\text { hydrogen } \\
\text { found (ppm) }\end{array}$ \\
\hline 1100 & 5 & - & 4.83 \\
100 & 3 & 9.4 & - \\
200 & 2 & 15.8 & - \\
400 & 1 & 20.1 & - \\
800 & 2 & 23.3 & - \\
\hline
\end{tabular}

\section{Determination of water evolved by heating glasses}

The glasses of highest quality and quartz are great use for the glassware and tubing of the vacuum apparatus. To realize this usage, the water evolved from some glasses on heating were determined by the present method.

The samples (mainly glass tubes) were cut about 1 $\mathrm{cm}$ in length, dipped overnight in a chromic-sulfuric acid mixture, washed and dried at $110^{\circ} \mathrm{C}$ for $3 \mathrm{hr}$. After these treatment, they were stored in various atmospheric conditions for $24 \mathrm{hr}$ at $20 \sim 25^{\circ} \mathrm{C}$ and then analyzed. All samples were heated at $300^{\circ} \mathrm{C}$. Although the temperature is not sufficient to remove the combined water in the sample completely, the temperature was chosen for the following two reasons. First, almost all of the glassware are not used at a temperature higher than $300^{\circ} \mathrm{C}$. Therefore, the determination of water evolved at the temperature was enough to provide necessary information for the 
Table 6 Determination of the water evolved from various glasses by heating at $300^{\circ} \mathrm{C}$.

\begin{tabular}{l|c|c}
\hline Kind of glass & $\begin{array}{c}\text { Relative humidity* } \\
(\%)\end{array}$ & $\begin{array}{c}\text { Water found } \\
\left(\mu \mathrm{g} / \mathrm{cm}^{2}\right)\end{array}$ \\
\hline Quartz & 53 & $\begin{array}{l}0.03 \\
0.05\end{array}$ \\
\hline Hard glass & 68 & $\begin{array}{l}0.16 \\
0.19\end{array}$ \\
\hline Pyrex & 53 & 0.20 \\
& 68 & 0.24 \\
\hline Soft glass & 53 & 4.1 \\
\hline Vycol glass & 53 & 7.1 \\
\hline Heatron T** & 58 & 0.27 \\
\hline Heatron $\mathrm{W}^{* *}$ & 58 & 0.30 \\
\hline
\end{tabular}

*Approximate values (Temperature: $20 \sim 25^{\circ} \mathrm{C}$ )

**Produced by Fuji Film Co. construction of an apparatus for water determination. Secondly, it is necessary to heat all of the samples at the same temperature for comparison of the results.

Table 6 shows the results obtained by this experiment. Soft glass evolved $4 \sim 7 \mu \mathrm{g} / \mathrm{cm}^{2}$ of water by this heating. The results show that the sample may release some combined water in it at this temperature. The water evolved from the glasses of high quality or Pyrex glass was one order lower than that of soft glass, and that from quartz was the least. The results in the table are also coincident with the value reported previousty ${ }^{(7)(8)}$.

A comparison between these results and the data in the preceding report indicates that borosilicate glasses. evolve only the surface water at temperatures lower than $300^{\circ} \mathrm{C}$, and that the materials for the construction of the apparatus in Fig. 1 are quite reasonable.

(7) I. M. Kolthoff and E. B. Sandell: Textbook of Quantitative Inorganic Analysis, 3rd. Ed., Macmillan-Maruzen (1964), p. 114.

(8) K. R. Lange: J. Collid Sci., 20 (1965), 231. 